\title{
Higher bee abundance, but not pest abundance, in landscapes with more agriculture on a late-flowering legume crop in tropical smallholder farms
}

\author{
Cassandra Vogel ${ }^{\text {Corresp., } 1}$, Timothy L Chunga ${ }^{2}$, Xiaoxuan Sun ${ }^{3}$, Katja Poveda $^{4}$, Ingolf Steffan-Dewenter ${ }^{1}$ \\ ${ }^{1}$ Department of animal ecology and tropical biology, Bayerische Julius-Maximilians-Universität Würzburg, Würzburg, Bayern, Germany \\ 2 Soils, Food and Healthy Communities, Ekwendeni, Mzimba district, Malawi \\ 3 Department of Geography, University of Western Ontario, London, Ontario, Canada \\ 4 Department of Entomology, Cornell University, Ithaca, New York State, United States \\ Corresponding Author: Cassandra Vogel \\ Email address: cassandra.vogel@uni-wuerzburg.de
}

Background: Landscape composition is known to affect both beneficial insect and pest communities on crop fields. Landscape composition therefore can impact ecosystem (dis)services provided by insects to crops. Though landscape effects on ecosystem service providers have been studied in large-scale agriculture in temperate regions, there is a lack of representation of tropical smallholder agriculture within this field of study, especially in sub-Sahara Africa. Legume crops can provide important food security and soil improvement benefits to vulnerable agriculturalists. However, legumes are dependent on pollinating insects, particularly bees (Hymenoptera: Apiformes) for production and are vulnerable to pests. We selected 10 pigeon pea (Fabacae: Cajunus cajan (L.)) fields in Malawi with varying proportions of semi-natural habitat and agricultural area within a $1 \mathrm{~km}$ radius to study: (1) how the proportion of seminatural habitat and agricultural area affects the abundance and richness of bees and abundance of florivorous blister beetles (Coleoptera: Melloidae), (2) if the proportion of flowers damaged and fruit set difference between open and bagged flowers are correlated with the proportion of semi-natural habitat or agricultural area and (3) if pigeon pea fruit set difference between open and bagged flowers in these landscapes was constrained by pest damage or improved by bee visitation.

Methods: We performed three, ten-minute, 15 meters, transects per field to assess blister beetle abundance and bee abundance and richness. Bees were captured and identified to (morpho)species. We assessed the proportion of flowers damaged by beetles during the flowering period. We performed a pollinator and pest exclusion experiment on 15 plants per field to assess whether fruit set was pollinator limited or constrained by pests.

Results: In our study, bee abundance was higher in areas with proportionally more agricultural area surrounding the fields. This effect was mostly driven by an increase in honeybees. Bee richness and beetle abundances were not affected by landscape characteristics, nor was flower damage or fruit set difference between bagged and open flowers. We did not observe a positive effect of bee density or richness, nor a negative effect of florivory, on fruit set difference.

Discussion: In our study area, pigeon pea flowers relatively late - well into the dry season. This could explain why we observe higher densities of bees in areas dominated by agriculture rather than in areas with more semi-natural habitat where resources for bees during this time of the year are scarce.

Therefore, late flowering legumes may be an important food resource for bees during a period of scarcity in the seasonal tropics. The differences in patterns between our study and those conducted in temperate

Peer) reviewing PDF | (2020:09:52483:2:0:NEW 16 Dec 2020) 
regions highlight the need for landscape-scale studies in areas outside the temperate region. 


\section{Higher bee abundance, but not pest abundance, in}

\section{2 landscapes with more agriculture on a late-flowering}

\section{3 legume crop in tropical smallholder farms}

5 Cassandra Vogel ${ }^{1}$, Timothy Chunga ${ }^{2}$, Xiaoxuan Sun $^{3}$, Katja Poveda ${ }^{4}$, Ingolf Steffan-Dewenter ${ }^{1}$

6

$7{ }^{1}$ Department of animal ecology and tropical biology, Bayerische Julius-Maximilians-Universität

8 Würzburg, Würzburg, Bayern, Germany

92 Soils, Food and Healthy Communities, Ekwendeni, Malawi

$10{ }^{3}$ Department of Geography, University of Western Ontario, London, Ontario, Canada

$11{ }^{4}$ Department of Entomology, Cornell University, Ithaca (NY), USA

12

13 Corresponding Author:

14 Cassandra Vogel,

15 Biocentre, Am Hubland, 97074, Würzburg, Germany

16 E-mail address: cassandra.vogel@uni-wuerzburg.de 


\section{Abstract}

18 Background. Landscape composition is known to affect both beneficial insect and pest communities on crop fields. Landscape composition therefore can impact ecosystem (dis)services provided by insects to crops. Though landscape effects on ecosystem service providers have been studied in large-scale agriculture in temperate regions, there is a lack of representation of tropical smallholder agriculture within this field of study, especially in subSahara Africa. Legume crops can provide important food security and soil improvement benefits to vulnerable agriculturalists. However, legumes are dependent on pollinating insects, particularly bees (Hymenoptera: Apiformes) for production and are vulnerable to pests. We selected 10 pigeon pea (Fabacae: Cajunus cajan (L.)) fields in Malawi with varying proportions of semi-natural habitat and agricultural area within a $1 \mathrm{~km}$ radius to study: (1) how the proportion of semi-natural habitat and agricultural area affects the abundance and richness of bees and abundance of florivorous blister beetles (Coleoptera: Melloidae), (2) if the proportion of flowers damaged and fruit set difference between open and bagged flowers are correlated with the proportion of semi-natural habitat or agricultural area and (3) if pigeon pea fruit set difference between open and bagged flowers in these landscapes was constrained by pest damage or improved by bee visitation.

Methods. We performed three, ten-minute, 15 meters, transects per field to assess blister beetle abundance and bee abundance and richness. Bees were captured and identified to

37 (morpho)species. We assessed the proportion of flowers damaged by beetles during the 38 flowering period. We performed a pollinator and pest exclusion experiment on 15 plants per field to assess whether fruit set was pollinator limited or constrained by pests. 
40

41 Results. In our study, bee abundance was higher in areas with proportionally more agricultural 42 area surrounding the fields. This effect was mostly driven by an increase in honeybees. Bee 43 richness and beetle abundances were not affected by landscape characteristics, nor was flower 44 damage or fruit set difference between bagged and open flowers. We did not observe a positive 45 effect of bee density or richness, nor a negative effect of florivory, on fruit set difference.

47 Discussion. In our study area, pigeon pea flowers relatively late - well into the dry season. This 48 could explain why we observe higher densities of bees in areas dominated by agriculture rather 49 than in areas with more semi-natural habitat where resources for bees during this time of the year 50 are scarce. Therefore, late flowering legumes may be an important food resource for bees during 51 a period of scarcity in the seasonal tropics. The differences in patterns between our study and

52 those conducted in temperate regions highlight the need for landscape-scale studies in areas 53 outside the temperate region. 


\section{Introduction}

55 Despite covering 16\% of global agricultural area and supporting some of the world's most

56 vulnerable populations, tropical smallholder agriculture has received relatively little attention in

57 agroecological research compared to large-scale agriculture in temperate regions (Steward et al.,

58 2014). Smallholder agriculture often exists within the world's most biodiverse but also

59 threatened landscapes, creating a necessity to develop smallholder agriculture in sustainable

60 ways that can both improve food security, whilst also safeguarding biodiversity and ecosystem

61 functions (Newbold et al., 2015; Samberg et al., 2016).

62

63 Insect communities in agricultural fields are driven by field management and the composition of

64 the surrounding landscape (Martin et al., 2019). These insect communities are known to be of

65 large importance to agricultural productivity. Pollination, particularly by bees, is a key

66 ecosystem service that is essential for enhancing the production of fruits and seeds in a majority

67 of crops (Garibaldi et al., 2013). On the other hand, herbivory of crops by insect pests is

68 estimated to cause more than $10 \%$ of pre-harvest losses (Oerke, 2006). A recent meta-analysis

69 has shown that pollinator density and richness benefits from a more complex landscape

70 containing more semi-natural habitat (SNH) (Dainese et al., 2019). For insect pests, this pattern

71 is more inconsistent between studies than for pollinators (Karp et al., 2018). Some studies show

72 decreasing pest pressure with increasing semi-natural habitat, often attributed to increased

73 occurrence of natural enemies in landscapes with more semi-natural habitat (Chaplin-Kramer \&

74 Kremen, 2012). Others suggest that semi-natural habitats can be a source of pests for crops

75 (Rusch et al., 2013) as, for example, non-crop habitat can be a refuge in which insect pests can 
76 survive outside of the growing season, only to recolonize crops once they start growing again

77 (Bianchi, Booij \& Tscharntke, 2006; Martin et al., 2019).

78

79 Despite being well studied in temperate larger-scale agriculture, larger knowledge gaps still exist on the understanding of landscape effects on beneficial and damaging insects in tropical

81

82

97 Pigeon pea (Fabacae: Cajunus cajan (L.)) is a legume crop with the potential to improve 98

smallholder agriculture, particularly in Africa (Otieno et al., 2020). Even if landscape-scale

studies in Africa are conducted, they usually focus on more commercially important crops, such as coffee and cotton (Vanlauwe et al., 2014). Crops more important to household food security are understudied in comparison, despite Africa's high rates of food insecurity (Sasson, 2012; Graeub et al., 2016). Food insecurity in Africa is caused in part by large crop losses due to pests, with farmers having limited access to pest management strategies, such as pesticides (Abate, van Huis \& Ampofo, 2000). Though pesticide use has increased in Africa in the last decades, pesticide application may not necessarily reduce crop losses by pests despite significant costs to the environment and to human health, particularly in sub-Saharan Africa, where lack of access to safety equipment and knowledge on how to correctly apply pesticides increases personal health risks to farmers and reduces the potential pest-control benefits (Oerke, 2006; de Bon et al., 2014; Isgren \& Andersson, 2020). This further highlights the need to understand what drives pest densities on important crops in the region in order to successfully manage them sustainably (de Bon et al., 2014). Particularly, legume crops are an important addition to cereal staple crops for providing food security and nutrition in sub-Saharan Africa (Otieno et al., 2020).

\section{6}

8 livelihoods of smallholder farmers due to its unique combination of high nutritional value, 
99 drought tolerance and nitrogen-fixing, soil-improving properties (Odeny, 2007). However, the 100 adoption of pigeon pea in our study area of northern Malawi has been constrained by perceived 101 yield losses by farmers due to a flower-feeding blister beetle (Coleoptera: Melloidae) (Mhango, 102 Snapp \& Phiri, 2013). The most commonly observed blister beetle on pigeon pea is a Hycleus 103 species (Appendix 1), which often feeds on the entire flower, including the reproductive parts.

104 The damaged flower, therefore, is unable to set fruit and produce any yield. Hycleus sp. is 105 common pest on legume crops in Africa (Lebesa et al., 2012). Average production in Malawi, 106 one of the larger pigeon pea growing regions in Africa, is less than a quarter of potential yields 107 (Odeny, 2007). In general, yield losses of pigeon pea due to insect pests range from 10-70\% 108 (Otieno et al., 2020), though the blister beetles are viewed as the most constraining to yield 109 (Mhango, Snapp \& Phiri, 2013). Pigeon pea can be up to 70\% self-pollinating (Saxena, Singh \& 110 Gupta, 1990). However, pollination has been shown to significantly improve fruit set of pigeon 111 pea compared to unvisited flowers. Particularly, bees of the genera Megachile and Xylocopa 112 have been found to be responsible for $20-90 \%$ of cross-pollination in this crop, with the 113 remainder being pollinated by other bee species or pollinating flies (Fohouo, Pando \& Tamesse, 114 2014; Otieno et al., 2015, 2020).

116 We investigated how the proportion of semi-natural habitat and agricultural area within a $1 \mathrm{~km}$ 117 radius around ten pigeon pea fields affects (1) the abundance and species richness of bees 118 (Hymenoptera: Apiformes) and the abundance of florivorous blister beetles, and (2) if the 119 proportion of flowers damaged and fruit set, is correlated with the proportion of agricultural area 120 or semi-natural habitat. Additionally, using an exclusion experiment, we (3) investigated if 
121 differences in fruit set between visited (open) and unvisited (bagged) flowers set in these

122 landscapes were constrained by pest damage and or improved by bee visitation. 


\section{Materials \& Methods}

124 Study area and field selection. We conducted our study from May to August 2019 in Mzimba 125 district, Northern Malawi. We selected ten already existing pigeon pea fields. We were given 126 verbal permission by all participating farmers to perform the study in their fields. In all the ten 127 fields, the pigeon pea crop had been planted at the onset of rains in December 2018, and were 128 initially intercropped with groundnut (Fabaceae: Arachis hypogaea L.). By the time we began 129 data collection, all the groundnut had already been harvested from all the fields. All pigeon pea 130 fields selected were planted with a local medium-maturing variety. The peak of bloom of this 131 pigeon pea variety is in May in our system. The duration of the flowering period can depend on 132 the climatic conditions, but in our region, the bloom lasted about 4 weeks. Malawi is located in 133 the seasonal tropics and experiences a marked peak in rainfall from December until the end of

134 February. In the months when we performed our experiment, there was no rainfall, as is typical 135 during this time of year (Mungai et al., 2016). The pigeon pea in our study region is a rain-fed 136 crop and is not irrigated or watered in any way, especially as pigeon pea is considered drought137 resistant (Odeny, 2007). All field activities, including land preparation and weeding, were 138 managed traditionally by hand. Farmers did not apply any chemicals such as herbicides and 139 pesticides on their fields. Fields ranged from $166 \mathrm{~m}^{2}$ to $577 \mathrm{~m}^{2}$ in size, with mean field size being $140332 \mathrm{~m}^{2}$. This is representative of field sizes of such a crop in the study region, where the average 141 smallholder total farm size ranges from only 0.5 to 1.4 hectares (FAO, 2018). Field size did not 142 correlate significantly with the proportion of semi-natural area $\left(\mathrm{F}_{2,6}=2.08, \mathrm{R}^{2}=0.21, \mathrm{p}=0.683\right)$ nor

143 with the proportion of agricultural area $\left(\mathrm{F}_{2,6}=2.08, \mathrm{R}^{2}=0.21, \mathrm{p}=0.088\right)$ in the $1 \mathrm{~km}$ radius 144 surrounding our fields. Field margins were vegetated with non-flowering weeds, grass or 145 shrubland. As it was the dry season during data collection, there were no flower margins on the 
146 fields. The surrounding agricultural fields where mostly empty, as the main staples in Malawi,

147 such as maize, was already harvested by this time in the season. Surrounding semi-natural habitat

148 was mainly composed of shrubland and forest. Generally, these are not actively managed but

149 may to some extent be exposed to exploitation by people due to economic activities such as

150 collection of firewood and grazing of livestock. We aimed to choose sites which were at a

151 distance of at least $2 \mathrm{~km}$ from each other. However, one site was found to have too large an

152 overlap with two others within a $1 \mathrm{~km}$ radius, with the center of this field being 883 and 885

153 meters away from the center of the nearest and second-nearest site, respectively. Therefore, this

154 site was subsequently dropped from any landscape analyses (Fig. 1). The remaining fields were

155 located within two non-correlating gradients of semi-natural habitat (ranging from $2 \%$ to $32 \%$ ),

156 and agricultural area (ranging from $25 \%$ to $75 \%$ ) within a $1 \mathrm{~km}$ radius surrounding the fields

$157\left(\mathrm{~F}_{1,7}=0.56, \mathrm{R}^{2}=0.07, \mathrm{p}=0.480\right)$. The $1 \mathrm{~km}$ radius was chosen, because we wanted our sites to be

158 independent from each other and prevent spatial autocorrelation. Additionally, since bees are

159 central place foragers, and their foraging ranges are limited, most bees would be sensitive to

160 landscape differences within the $1 \mathrm{~km}$ radius (Steffan-Dewenter et al., 2002; Zurbuchen et al.,

161 2010). Other habitats in our study area included some built-up areas (such as buildings and

162 roads) and bare rock (mostly on hilltops). Although honeybees are native to the area (Requier et

163 al., 2019), we found no honeybee hives in any of the fields across our study area. Moreover,

164 none of the farmers we worked with kept honeybees on any of their fields. In our study area,

165 honeybees are rarely actively placed in fields by farmers, but rather encouraged to nest nearby by

166 placing traditional beehives near fields where they may be passively colonized by a honeybee

167 colony (Appendix 2) (Requier et al., 2019). To our knowledge, there were no such hives placed

168 near any of our study fields. 
170 Landscape analysis. For the land use and land cover classification, we acquired three cloud-free

171 Sentinel-2 satellite images from 2019 from the Copernicus Open Access Hub

172 (https://scihub.copernicus.eu/dhus/\#/home). One image was taken on November 8th 2019, and

173 two are from November 15th 2019, which is in the late dry season in Malawi. Though this is not

174 the same time as our field study period, the images still show the general land use and land cover

175 in our study area and we assume this has not changed significantly between May and November.

176 The methodology for land cover analysis involved images pre-processing, supervised maximum

177 likelihood classification, post-classification, and accuracy assessment (Appendix 3). First, we

178 pre-processed the Sentinel-2 images, which consisted of the atmospheric correction, image

179 resampling, layer stacking, seamless mosaic, and image subsetting. Then, we conducted

180 Maximum Likelihood classification using training samples generated from fieldwork and Google

181 Earth. The classification includes six classes, which are: (1) bare land/road; (2) shrubland; (3)

182 agricultural land; (4) water/riverbed; (5) settlement; (6) trees/forest. However, in this study, we

183 only used classification (2) shrubland and (6) trees/forest together which we defined as semi-

184 natural habitat (SNH) and (3) agricultural area. Finally, we performed post-classification and

185 accuracy assessment. The overall accuracy of the classification is $85.1 \%$, with a Kappa

186 Coefficient of 0.817 . We used tabulate area tools in ArcGIS to get the area and proportion of the 187 types of land use and land cover for all buffer zones of each site (Esri, 2020).

189 Bee and beetle collection. To assess bee and blister beetle densities, we walked straight 15

190 meter transects for 10 minutes across the most flower rich area of the field on three separate

191 dates, resulting in 30-minute total sampling time per field. One round of transects at each field 
192 was finished before a new round was started, resulting in a pause of about a week between

193 individual sampling dates at each field. All flower-visiting bees one-meter left and right of the

194 investigator were captured with an insect net for subsequent identification. All blister beetles

195 observed one meter left and right of the investigator were counted, taking care not to count the

196 same individual twice. To obtain a proxy for planting density, we counted the number of pigeon

197 pea shrubs across each transect. Planting density across transects did not correlate with the 198 proportion of agricultural area $(p=0.786)$ or semi-natural habitat $(p=0.338)\left(F_{2,7}=0.53, R^{2}=0.13\right.$, $199 \mathrm{p}=0.610)$. Transects were walked between the 8th and 29th of May 2019, between 8:00 and 200 16:00, when weather conditions were not windy (Beaufort scale $<3$ ) or too cloudy $(<80 \%$ cloud 201 cover), and thus deemed favorable for bee foraging. It did not rain, and temperatures ranged from $20218^{\circ} \mathrm{C}$ to $25^{\circ} \mathrm{C}$ throughout our sampling period. Visitation order on a specific day was randomized 203 so that each field was visited during a different time of the day during consecutive transects. 204

205 Bee identification. Captured bees were identified to genus or subgenus level with the guides 206 from Michener (2007) and Connal, Kuhlmann \& Pauly (2010) and grouped by (morpho)species. 207 Captured bees are stored at the Biocentre, University of Würzburg, Germany. 208

209 Flower exclusion and fruit set data. At each site, we marked 15 pigeon pea plants in a 210 continuous line from the edge of the field inwards. On each plant, we tagged one cluster of 211 flowers as the open control. This cluster was accessible to all visitors, both pollinators and 212 herbivores. On the same plant, we then paired this tagged cluster with another cluster of flowers 213 to which all visitors (pollinators as well as herbivores) were excluded using a 9x12 cm organza 214 bag. The number of flowers in the tagged and bagged clusters where counted. The bags had a 
215 mesh size of $0.6 \mathrm{~mm}$ - small enough to exclude any insect. Although exclusion of pollinators and 216 pests in different treatments would have been ideal, this could not be done, since the beetles feed

217 on the flowers, during the same time that pollinators are visiting them. Our hypothesis was that if 218 the fields experience high pest pressure, bagged clusters will perform better, as they are protected 219 from herbivory. On the other hand, we assumed that in fields where there is a large amount of 220 ambient pollination and low flower damage by herbivores, the open clusters would outperform 221 the bagged ones. In fields with little ambient pollination, or where the benefits of pollination are 222 cancelled out by pest damage, open and bagged flowers would perform similarly. Plants were 223 tagged and bagged upon the first visit to the field before the flowers had opened and we removed 224 the bags when all the flowers in the cluster had finished blooming, which took approximately 225 two weeks. After removing the bags, the pigeon pea pods were left to mature in the field. 226

227 Fruit set data was collected from the 3rd of July to the 2nd of August 2019. To assess fruit set 228 (the proportion of flowers turning into pods) as a measure of pollinator effectiveness, we counted 229 the number of flowers that were originally present on the tagged clusters, and then counted the 230 number of pods formed in the same clusters. The number of pods formed divided by the number 231 of flowers was taken as a measure of fruit set per cluster. In one field, damage by cattle grazing 232 destroyed the tagged plants and we were unable to collect data on fruit set there.

234 Blister beetle damage assessment. To get a measure of the proportion of flowers damaged by 235 blister beetle herbivory/florivory, we assessed flower damage three times at eight of the sites and 236 twice at two of the sites. We used the open cluster of the 15 pigeon pea shrubs we tagged in each 237 field for this. We counted the number of flowers per cluster and the number of these flowers that 
238 showed signs of chewing herbivory typical of blister beetles. With this data we calculated the 239 proportion of flowers damaged by blister beetles.

240

241 Data analysis. To test whether landscape composition affected bee and blister beetle abundance, 242 we summed the number of individuals across all three transects. For bee richness, we used the 243 cumulative bee richness across dates per field. We first tested if bee abundance, bee richness and 244 blister beetle abundance were independent of planting density across transects or field size

245 (Appendix 4). We then tested how the proportion of semi-natural habitat and agricultural area 246 within the $1 \mathrm{~km}$ radius affected bee and blister beetle abundance using a linear regression. To test 247 whether landscape composition affected bee richness, we used the bee richness at each site and 248 again tested this against the landscape variables using a linear regression. To test to what extent 249 our patterns where driven by the presence of honeybees (Apis mellifera L.), the most abundant 250 pollinator in our system, we tested bee abundance against the two landscape variables including 251 and excluding honeybees from the analysis.

252

253 To test if landscape variables affected blister beetle damage in our fields, we calculated for each 254 of the 15 plants the mean proportion of flowers damaged by herbivory across the flowering 255 season from the three dates. Since our data were zero-inflated (no flowers damaged), we used a 256 negative-binomial mixed model using the 'glmer.nb' call from the package 'Ime4' (Bates et al.,

257 2019). We tested the mean proportion of flowers damaged against the proportion of semi-natural

258 habitat and agricultural area. Since we had repeated measures within fields, we used field as a 259 random factor in this model. 
261 To test whether landscapes affected the differences in fruit set between bagged and open clusters,

262 we calculated the proportion of flowers that set fruit for each cluster. Then, we subtracted the

263 proportion of fruit set of the bagged cluster from that of the open cluster. Again, using the

264 package 'Ime4' (Bates et al., 2019), we calculated mixed effects models testing the difference in

265 fruit set against the two landscape variables, using field as a random factor to account for

266 repeated measures per field. In this analysis, we had to exclude 31 out of 120 plants due

267 tampering or missing tags.

268

269 Finally, to calculate the effect of bee visitation and beetle damage on fruit set difference between

270 the bagged and open clusters, we used mixed models. To do this, we took the total number of

271 bees recorded at each site, and divided this by the total number of pigeon pea shrubs across our

272 transects. This gives us bee density per crop plant, which we used as a proxy for bee visitor

273 density per pigeon pea shrub. We then calculated the effect of bee density, bee richness and the

274 proportion of flowers damaged per plant on the difference in fruit set between the paired clusters,

275 using field as a random factor to account for nestedness. We chose to use flower damage, rather

276 than beetle abundance or density in this model because we deemed it a more concrete

277 representation of the pest pressure the plants experienced, though blister beetle abundance and

278 the proportion of damage was correlated $\left(\mathrm{F}_{1,418}=4.88, \mathrm{R}^{2}=0.01, \mathrm{p}=0.028\right)$. In this analysis, we had 279 to exclude 34 out of 135 pigeon pea shrubs due to tampering or missing tags.

280

281 All models were tested for and met the assumptions of distributions, normality (of residuals) and

282 heteroscedasticity. All statistical analyses were performed in R version 4.0.1 (R Core Team, 283 2020). 


\section{Results}

285 Landscape effects on bee abundance, bee richness, and blister beetle abundance.

286 In total, we observed 84 bees of 13 species (Appendix 5) and 127 blister beetles across the five

287 hours of transects during our study period. The proportion of semi-natural habitat within a $1 \mathrm{~km}$

288 radius of the fields did not affect bee abundance $\left(\mathrm{F}_{2,6}=5.53, \mathrm{R}^{2}=0.65, \mathrm{p}=0.775\right)$ (Fig. 2a) or

289 richness $\left(\mathrm{F}_{2,6}=1.38, \mathrm{R}^{2}=0.32, \mathrm{p}=0.203\right)$ (Fig. 2c), and neither did it affect blister beetle

290 abundance $\left(\mathrm{F}_{2,6}=1.58, \mathrm{R}^{2}=0.35, \mathrm{p}=0.538\right)$ (Fig. 2e). The proportion of agricultural area positively

291 affected bee abundance $\left(\mathrm{F}_{2,6}=5.53, \mathrm{R}^{2}=0.65, \mathrm{p}=0.0209\right)$ (Fig. 2b), though this pattern was

292 primarily driven by higher honeybee densities at high-agricultural area sites, as solitary bees

293 alone did not respond significantly to landscape factors. The pattern was additive, as honeybee

294 densities alone did also not show significant patterns, and it was just the analysis with honeybees

295 and solitary bees together that showed a result (Appendix 6). However, agricultural area did not

296 affect bee richness $\left(\mathrm{F}_{2,6}=1.38, \mathrm{R}^{2}=0.32, \mathrm{p}=0.683\right)$ (Fig. 2d) nor blister beetle abundance in the

297 fields $\left(\mathrm{F}_{2,6}=1.58, \mathrm{R}^{2}=0.35, \mathrm{p}=0.127\right)($ Fig. 2f $)($ Table 1).

298

299 Landscape effects on blister beetle damage and fruit set difference.

300 The proportion of flower damage ranged from zero to 0.36 , with a mean of 0.06 . There was no

301 effect of the proportion of semi-natural habitat nor agricultural area on the proportion of flowers

302 damaged by blister beetles on the tagged open clusters (Appendix 7). The number of open

303 clusters that a higher proportion of damage than 0.05 varied from 2 to 12 clusters per site, but

304 this did not correlate to either proportion of semi-natural habitat $\left(\mathrm{F}_{2,6}=0.01, \mathrm{R}^{2}=0.001, \mathrm{p}=0.923\right)$

305 or agricultural area $\left(\mathrm{F}_{2,6}=0.01, \mathrm{R}^{2}=0.001, \mathrm{p}=0.998\right)$. The proportion of fruit set on open clusters

306 ranged from 0 (none of the flowers set fruit) to 1 (all flowers set fruit) with a mean fruit set 
307 proportion of 0.37 . The proportion of fruit set on bagged clusters also ranged from 0 to 1 with a 308 mean fruit set proportion of 0.26 . Fruit set difference (open-bagged) ranged from -1 to 1 and had 309 a mean of 0.11 . There was no effect of the landscape variables on the fruit set difference between 310 the open and bagged flower clusters (Table 2) (Appendix 7).

311

312 Effects of bees and blister beetle damage on fruit set difference.

313 We observed no effects of bee density or bee richness nor of blister beetle damage on the 314 proportional difference in fruit set (Table 3) (Appendix 8). 


\section{Discussion}

316 In our study, we aimed to investigate how differences in landscape composition may drive

317 ecosystem services and disservices on smallholder farms in the tropics. We find that increasing

318 agricultural area surrounding our crop increases the abundance of bees, driven primarily by an

319 increase in honeybees, on our studied fields. This seems in contrast with most studies that

320 indicate that increasing semi-natural habitat in the surrounding area increases pollinator

321 abundance in crop fields (Kennedy et al., 2013). Another study on pigeon pea, conducted in

322 Kenya, also showed that fields located closer to semi-natural habitat also had a lower abundance

323 of pollinators (Otieno et al., 2011), indicating that such a pattern may be more common in the

324 African seasonal tropics. In our system, pigeon pea flowers during May, which is well into the

325 dry season in our study system (Mungai et al., 2016). In general, bee abundance in our study

326 system was low, which is expected in the seasonal tropics where the peak in insect activity is

327 usually on the onset of the wet season, which in our study area would be around December

328 (Kishimoto-Yamada \& Itioka, 2015). Since abundances were mostly driven by honeybees, it can

329 be assumed this could be due to the larger number of colonies nesting in agricultural areas

330 compared to areas with less agricultural area. Relative to solitary bees, honeybees also have a

331 larger foraging range, which means they may be more successful in finding resource-rich

332 flowering fields in a resource-poor environment over larger distances from their nests.

333 Additionally, they recruit colony mates to forage there, which is not the case for solitary bees,

334 which do not live in colonies and have more limited foraging ranges (Steffan-Dewenter \& Kuhn,

335 2003; Zurbuchen et al., 2010). Considering the resource scarcity during our study period, it is

336 reasonable to observe higher densities of bees in agricultural areas, where there are still some 
337 flowering crops providing resources to bees, which would be almost absent in semi-natural areas

338 during this time of year.

339

340 Aside from one site, most of our sites showed similar performance between bagged and open

341 clusters. In our study, damage by blister beetles did not predict differences in fruit set between

342 bagged and open flower clusters. Though we do not rule out that blister beetles contribute to

343 losses in fruit set, our data suggests blister beetles are not as significant a pest on pigeon pea in

344 our study area as commonly believed. Farmers often state blister beetles as a significant

345 constraint to growing pigeon pea in our study area, perhaps because they are conspicuous

346 (Mungai et al., 2016). In our study, we used existing pigeon pea fields, and did not plant the

347 fields specifically. Since no pigeon pea fields existed in areas where farmers did not grow pigeon

348 pea due to extensive pest damage, we did not investigate those areas where blister beetle

349 densities are perceived to be highest. It could be that the contrast between our sites is not large

350 enough to observe possible differences since these higher extremes are not included. This could

351 contribute to the fact that we did not observe any differences in blister beetle abundance on

352 pigeon pea fields and resulting flower damage within the scope of our study, and pest damage

353 was similar across sites.

354

355 Increasing bee densities did not improve the fruit set of open-pollinated flower clusters compared

356 to bagged clusters. This is in contrast with many studies showing improved agricultural

357 production with increased flower visitation, particularly on small farms like those in our study

358 system (Garibaldi et al., 2016), and also on an earlier study on pigeon pea (Otieno et al., 2011).

359 Additionally, we did not find an effect of bee richness on fruit set, which is also not consistent 
360 with other studies on pollinator dependent crops (Garibaldi et al., 2016; Dainese et al., 2019). In

361 our study, higher bee abundances were mostly driven by increased honeybee abundance.

362 Previous studies indicate that honeybee visitation often does not benefit crop yield (Garibaldi et

363 al., 2013), which could explain the lack of increased fruit set in our sites with higher bee

364 abundance. Numerous studies have shown that pollination and pest damage may interactively

365 shape crop yields (Lundin et al., 2013; Bartomeus, Gagic \& Bommarco, 2015). In our study,

366 such effects may also be at play, but we cannot distinguish them since we were unable to test the

367 interactive effects due to low sample size.

368

369 In our study area, honeybees were the most abundant bees, and therefore important in driving

370 higher bee abundances in agricultural areas. In contrast to temperate systems, in Africa, up to

$37190 \%$ of honeybee colonies occur in the wild, and honeybee keeping as a practice is still

372 underdeveloped and small-scale, with no impact of humans on breeding (Requier et al., 2019).

373 Therefore, like both social and solitary wild bees in temperate systems, honeybees in our system

374 have conservation value as a part of the local bee biodiversity (Dietemann, Pirk \& Crewe, 2009).

375 Though bee visitation did not directly benefit fruit set of this particular crop, the fact that a crop

376 flowers during this time of year may still be important, as this could provide an important flower

377 resource, particularly for social bees, that are still active during this season of scarcity in our

378 study system. If it helps individual bees and honeybee colonies to survive this time of the year, it

379 may benefit farmers on the long run if these pollinator populations are conserved until the next

380 growing season when the farmers may be growing early flowering crops that are more strongly

381 pollinator dependent. 


\section{Conclusions}

383 Many studies show the effect of landscape composition on the abundance and richness of 384 pollinators and pests, and that particularly in the case of pests, these patterns are not always 385 consistent (Kennedy et al., 2013; Karp et al., 2018). Our study shows that these patterns may be 386 quite different in tropical smallholder agriculture compared to better studied tropical agroforestry 387 and temperate annual cropping systems. Differences in patterns in comparison to temperate 388 systems highlight the necessity to study different climatic and growing contexts better. Our study 389 indicates that late-flowering crops provide an important floral resource during a scarce period in 390 the seasonal tropics and are therefore an important component in sustainable agriculture in these 391 parts of the world. 


\section{Acknowledgements}

393 We are grateful to Innocent Mhoni, Pressings Moyo, Tapiwa Mkandawire and Mwapi

394 Mkandawire for their assistance in the field. We are also grateful to the leadership of the Soils

395 Food and Healthy Communities (SFHC), Esther Lupafya, Laifofo Dakishoni and Lizzie Shumba

396 for all their help streamlining all practical aspects of performing the study in Malawi. We are

397 grateful to Aaron Iverson for his input on the data and practical advice during the field season.

398 We also owe Jinfei Wang and Daniel Kpienbaareh our thanks for the teamwork required to 399 complete the landscape analysis. We also thank the reviewers for their contribution to the

400 improvement of the manuscript. Finally, we owe our gratitude to all the farmers who allowed us 401 to perform our experiments in their fields. 


\section{References}

403 Abate T, van Huis A, Ampofo JKO. 2000. Pest Management Strategies in Traditional

404 Agriculture: An African Perspective. Annual Review of Entomology 45:631-659. DOI:

405 10.1146/annurev.ento.45.1.631.

406 Bartomeus I, Gagic V, Bommarco R. 2015. Pollinators, pests and soil properties interactively

407 shape oilseed rape yield. Basic and Applied Ecology 16:737-745. DOI:

408 10.1016/j.baae.2015.07.004.

409 Bates D, Maechler M, Bolker B, Christensen RHB, Singmann H, Dai B, Scheipl F, Grothendieck 410 G. 2019. Package "lme4."

411 Bianchi FJJA, Booij CJH, Tscharntke T. 2006. Sustainable pest regulation in agricultural 412 landscapes: a review on landscape composition, biodiversity and natural pest control.

413 Proceedings of the Royal Society B: Biological Sciences 273:1715-1727. DOI:

$414 \quad 10.1098 /$ rspb.2006.3530.

415 de Bon H, Huat J, Parrot L, Sinzogan A, Martin T, Malézieux E, Vayssières J-F. 2014. Pesticide 416 risks from fruit and vegetable pest management by small farmers in sub-Saharan Africa. A 417 review. Agronomy for Sustainable Development 34:723-736. DOI: 10.1007/s13593-014-0216-7.

418 Chaplin-Kramer R, Kremen C. 2012. Pest control experiments show benefits of complexity at 419 landscape and local scales. Ecological Applications 22:1936-1948. DOI: 10.1890/11-1844.1.

420 Connal E, Kuhlmann M, Pauly A. 2010. The Bee Genera and Subgenera of sub-Saharan Africa. 421 Abc Taxa.

422 Dainese M, Martin EA, Aizen MA, Albrecht M, Bartomeus I, Bommarco R, Carvalheiro LG, 423 Chaplin-Kramer R, Gagic V, Garibaldi LA, Ghazoul J, Grab H, Jonsson M, Karp DS, Kennedy 
424 CM, Kleijn D, Kremen C, Landis DA, Letourneau DK, Marini L, Poveda K, Rader R, Smith HG, 425 Tscharntke T, Andersson GKS, Badenhausser I, Baensch S, Bezerra ADM, Caballero-Lopez B, 426 Cavigliasso P, Classen A, Cusser S, Dudenhöffer JH, Ekroos J, Fijen T, Franck P, Freitas BM, 427 Garratt MPD, Gratton C, Hipólito J, Holzschuh A, Hunt L, Iverson AL, Jha S, Keasar T, Kim 428 TN, Kishinevsky M, Klatt BK, Klein A-M, Krewenka KM, Krishnan S, Larsen AE, Lavigne C, 429 Liere H, Maas B, Mallinger RE, Pachon EM, Martínez-Salinas A, Meehan TD, Mitchell MGE, 430 Molina GAR, Nesper M, Nilsson L, O’Rourke ME, Peters MK, Ple M, Ramos D de L, 431 Rosenheim JA, Rundlöf M, Rusch A, Sáez A, Scheper J, Schleuning M, Schmack JM, Sciligo 432 AR, Seymour C, Stanley DA, Stewart R, Stout JC, Sutter L, Takada MB, Taki H, Tamburini G, 433 Tschumi M, Viana BF, Westphal C, Willcox BK, Wratten SD, Yoshioka A, Zaragoza-Trello C, 434 Zhang W, Zou Y, Steffan-Dewenter I. 2019. A global synthesis reveals biodiversity-mediated 435 benefits for crop production. SCIENCE ADVANCES:14.

436 Dietemann V, Pirk CWW, Crewe R. 2009. Is there a need for conservation of honeybees in 437 Africa? Apidologie 40:285-295. DOI: 10.1051/apido/2009013.

438 Esri. 2020. ArcGIS Pro 2.6.

439 FAO. 2018. FAO Small Family Farms Country Factsheet: Malawi.

440 Fohouo F-NT, Pando JB, Tamesse JL. 2014. Pollination efficiency of Xylocopa olivacea

441 (Hymenoptera: Apidae) on Cajanus cajan (Fabaceae) flowers at Yaoundé, Cameroon.

442 International Journal of Tropical Insect Science 34:138-148. DOI:

$44310.1017 / \mathrm{S} 1742758414000307$.

444 Garibaldi LA, Carvalheiro LG, Vaissiere BE, Gemmill-Herren B, Hipolito J, Freitas BM, Ngo

445 HT, Azzu N, Saez A, Astrom J, An J, Blochtein B, Buchori D, Garcia FJC, Oliveira da Silva F,

446 Devkota K, Ribeiro M d. F, Freitas L, Gaglianone MC, Goss M, Irshad M, Kasina M, Filho 
447 AJSP, Kiill LHP, Kwapong P, Parra GN, Pires C, Pires V, Rawal RS, Rizali A, Saraiva AM, 448 Veldtman R, Viana BF, Witter S, Zhang H. 2016. Mutually beneficial pollinator diversity and 449 crop yield outcomes in small and large farms. Science 351:388-391. DOI:

$450 \quad 10.1126 /$ science.aac7287.

451 Garibaldi LA, Steffan-Dewenter I, Winfree R, Aizen MA, Bommarco R, Cunningham SA, 452 Kremen C, Carvalheiro LG, Harder LD, Afik O, Bartomeus I, Benjamin F, Boreux V, Cariveau 453 D, Chacoff NP, Dudenhoffer JH, Freitas BM, Ghazoul J, Greenleaf S, Hipolito J, Holzschuh A, 454 Howlett B, Isaacs R, Javorek SK, Kennedy CM, Krewenka KM, Krishnan S, Mandelik Y, 455 Mayfield MM, Motzke I, Munyuli T, Nault BA, Otieno M, Petersen J, Pisanty G, Potts SG, 456 Rader R, Ricketts TH, Rundlof M, Seymour CL, Schuepp C, Szentgyorgyi H, Taki H, 457 Tscharntke T, Vergara CH, Viana BF, Wanger TC, Westphal C, Williams N, Klein AM. 2013. 458 Wild Pollinators Enhance Fruit Set of Crops Regardless of Honey Bee Abundance. Science 459 339:1608-1611. DOI: 10.1126/science.1230200.

460 Graeub BE, Chappell MJ, Wittman H, Ledermann S, Kerr RB, Gemmill-Herren B. 2016. The 461 State of Family Farms in the World. World Development 87:1-15. DOI:

$462 \quad 10.1016 /$ j.worlddev.2015.05.012.

463 Isgren E, Andersson E. 2020. An Environmental Justice Perspective on Smallholder Pesticide 464 Use in Sub-Saharan Africa. The Journal of Environment \& Development:107049652097440. 465 DOI: $10.1177 / 1070496520974407$.

466 Karp DS, Chaplin-Kramer R, Meehan TD, Martin EA, DeClerck F, Grab H, Gratton C, Hunt L, 467 Larsen AE, Martínez-Salinas A, O’Rourke ME, Rusch A, Poveda K, Jonsson M, Rosenheim JA, 468 Schellhorn NA, Tscharntke T, Wratten SD, Zhang W, Iverson AL, Adler LS, Albrecht M, 469 Alignier A, Angelella GM, Zubair Anjum M, Avelino J, Batáry P, Baveco JM, Bianchi FJJA, 
470 Birkhofer K, Bohnenblust EW, Bommarco R, Brewer MJ, Caballero-López B, Carrière Y, 471 Carvalheiro LG, Cayuela L, Centrella M, Ćetković A, Henri DC, Chabert A, Costamagna AC, 472 De la Mora A, de Kraker J, Desneux N, Diehl E, Diekötter T, Dormann CF, Eckberg JO, Entling 473 MH, Fiedler D, Franck P, Frank van Veen FJ, Frank T, Gagic V, Garratt MPD, Getachew A, 474 Gonthier DJ, Goodell PB, Graziosi I, Groves RL, Gurr GM, Hajian-Forooshani Z, Heimpel GE, 475 Herrmann JD, Huseth AS, Inclán DJ, Ingrao AJ, Iv P, Jacot K, Johnson GA, Jones L, Kaiser M, 476 Kaser JM, Keasar T, Kim TN, Kishinevsky M, Landis DA, Lavandero B, Lavigne C, Le Ralec 477 A, Lemessa D, Letourneau DK, Liere H, Lu Y, Lubin Y, Luttermoser T, Maas B, Mace K, 478 Madeira F, Mader V, Cortesero AM, Marini L, Martinez E, Martinson HM, Menozzi P, Mitchell 479 MGE, Miyashita T, Molina GAR, Molina-Montenegro MA, O’Neal ME, Opatovsky I, Ortiz480 Martinez S, Nash M, Östman Ö, Ouin A, Pak D, Paredes D, Parsa S, Parry H, Perez-Alvarez R, 481 Perović DJ, Peterson JA, Petit S, Philpott SM, Plantegenest M, Plećaš M, Pluess T, Pons X, Potts 482 SG, Pywell RF, Ragsdale DW, Rand TA, Raymond L, Ricci B, Sargent C, Sarthou J-P, Saulais J, 483 Schäckermann J, Schmidt NP, Schneider G, Schüepp C, Sivakoff FS, Smith HG, Stack Whitney 484 K, Stutz S, Szendrei Z, Takada MB, Taki H, Tamburini G, Thomson LJ, Tricault Y, Tsafack N, 485 Tschumi M, Valantin-Morison M, Van Trinh M, van der Werf W, Vierling KT, Werling BP, 486 Wickens JB, Wickens VJ, Woodcock BA, Wyckhuys K, Xiao H, Yasuda M, Yoshioka A, Zou 487 Y. 2018. Crop pests and predators exhibit inconsistent responses to surrounding landscape 488 composition. Proceedings of the National Academy of Sciences 115:E7863-E7870. DOI: 489 10.1073/pnas.1800042115.

490 Kennedy CM, Lonsdorf E, Neel MC, Williams NM, Ricketts TH, Winfree R, Bommarco R, 491 Brittain C, Burley AL, Cariveau D, Carvalheiro LG, Chacoff NP, Cunningham SA, Danforth 492 BN, Dudenhöffer J-H, Elle E, Gaines HR, Garibaldi LA, Gratton C, Holzschuh A, Isaacs R, 
493 Javorek SK, Jha S, Klein AM, Krewenka K, Mandelik Y, Mayfield MM, Morandin L, Neame 494 LA, Otieno M, Park M, Potts SG, Rundlöf M, Saez A, Steffan-Dewenter I, Taki H, Viana BF, 495 Westphal C, Wilson JK, Greenleaf SS, Kremen C. 2013. A global quantitative synthesis of local 496 and landscape effects on wild bee pollinators in agroecosystems. Ecology Letters 16:584-599. 497 DOI: 10.1111/ele.12082.

498 Kishimoto-Yamada K, Itioka T. 2015. How much have we learned about seasonality in tropical 499 insect abundance since Wolda (1988)?: Seasonality in tropical insect abundance. Entomological 500 Science 18:407-419. DOI: 10.1111/ens.12134.

501 Lebesa LN, Khan ZR, Krüger K, Bruce TJA, Hassanali A, Pickett JA. 2012. Farmers’ 502 knowledge and perceptions of blister beetles, Hycleus spp. (Coleoptera: Meloidae), as pest 503 herbivores of Desmodium legumes in western Kenya. International Journal of Pest Management 504 58:165-174. DOI: 10.1080/09670874.2012.673032.

505 Lundin O, Smith HG, Rundlöf M, Bommarco R. 2013. When ecosystem services interact: crop 506 pollination benefits depend on the level of pest control. Proceedings of the Royal Society B:

507 Biological Sciences 280:20122243. DOI: 10.1098/rspb.2012.2243.

508 Martin EA, Dainese M, Clough Y, Báldi A, Bommarco R, Gagic V, Garratt MPD, Holzschuh A, 509 Kleijn D, Kovács-Hostyánszki A, Marini L, Potts SG, Smith HG, Al Hassan D, Albrecht M, 510 Andersson GKS, Asís JD, Aviron S, Balzan MV, Baños-Picón L, Bartomeus I, Batáry P, Burel 511 F, Caballero-López B, Concepción ED, Coudrain V, Dänhardt J, Diaz M, Diekötter T, Dormann 512 CF, Duflot R, Entling MH, Farwig N, Fischer C, Frank T, Garibaldi LA, Hermann J, Herzog F, 513 Inclán D, Jacot K, Jauker F, Jeanneret P, Kaiser M, Krauss J, Le Féon V, Marshall J, Moonen A, 514 Moreno G, Riedinger V, Rundlöf M, Rusch A, Scheper J, Schneider G, Schüepp C, Stutz S, 515 Sutter L, Tamburini G, Thies C, Tormos J, Tscharntke T, Tschumi M, Uzman D, Wagner C, 
516 Zubair-Anjum M, Steffan-Dewenter I. 2019. The interplay of landscape composition and 517 configuration: new pathways to manage functional biodiversity and agroecosystem services 518 across Europe. Ecology Letters 22:1083-1094. DOI: 10.1111/ele.13265.

519 Mhango WG, Snapp SS, Phiri GYK. 2013. Opportunities and constraints to legume 520 diversification for sustainable maize production on smallholder farms in Malawi. Renewable 521 Agriculture and Food Systems 28:234-244. DOI: 10.1017/S1742170512000178.

522 Michener CD. 2007. The bees of the world. Baltimore: The Johns Hopkins University Press.

523 Mungai LM, Snapp S, Messina JP, Chikowo R, Smith A, Anders E, Richardson RB, Li G. 2016.

524 Smallholder Farms and the Potential for Sustainable Intensification. Frontiers in Plant Science 7. 525 DOI: 10.3389/fpls.2016.01720.

526 Newbold T, Hudson LN, Hill SLL, Contu S, Lysenko I, Senior RA, Börger L, Bennett DJ, 527 Choimes A, Collen B, Day J, De Palma A, Díaz S, Echeverria-Londoño S, Edgar MJ, Feldman 528 A, Garon M, Harrison MLK, Alhusseini T, Ingram DJ, Itescu Y, Kattge J, Kemp V, Kirkpatrick 529 L, Kleyer M, Correia DLP, Martin CD, Meiri S, Novosolov M, Pan Y, Phillips HRP, Purves 530 DW, Robinson A, Simpson J, Tuck SL, Weiher E, White HJ, Ewers RM, Mace GM, 531 Scharlemann JPW, Purvis A. 2015. Global effects of land use on local terrestrial biodiversity. 532 Nature 520:45-50. DOI: 10.1038/nature14324.

533 Odeny DA. 2007. The potential of pigeonpea (Cajanus cajan (L.) Millsp.) in Africa. Natural 534 Resources Forum 31:297-305.

535 Oerke E-C. 2006. Crop losses to pests. The Journal of Agricultural Science 144:31-43. DOI: $53610.1017 / \mathrm{S} 0021859605005708$. 
537 Otieno M, Steffan-Dewenter I, Potts SG, Kinuthia W, Kasina M, Garratt MPD. 2020. (In press)

538 Enhancing legume crop pollination and natural pest regulation for improved food security in

539 changing African landscapes. Global Food Security.

540 Otieno M, Woodcock BA, Wilby A, Vogiatzakis IN, Mauchline AL, Gikungu MW, Potts SG.

541 2011. Local management and landscape drivers of pollination and biological control services in a

542 Kenyan agro-ecosystem. Biological Conservation 144:2424-2431. DOI:

543 10.1016/j.biocon.2011.06.013.

544 R Core Team. 2020. R: A language and environment for statistical computing. Vienna, Austria:

545 R Foundation for Statistical Computing.

546 Requier F, Garnery L, Kohl PL, Njovu HK, Pirk CWW, Crewe RM, Steffan-Dewenter I. 2019.

547 The Conservation of Native Honey Bees Is Crucial. Trends in Ecology \& Evolution 34:789-798.

548 DOI: 10.1016/j.tree.2019.04.008.

549 Rusch A, Valantin-Morison M, Sarthou JP, Roger-Estrade J. 2013. Effect of crop management 550 and landscape context on insect pest populations and crop damage. Agriculture, Ecosystems \&

551 Environment 166:118-125. DOI: 10.1016/j.agee.2011.05.004.

552 Samberg LH, Gerber JS, Ramankutty N, Herrero M, West PC. 2016. Subnational distribution of

553 average farm size and smallholder contributions to global food production. Environmental

554 Research Letters 11:124010. DOI: 10.1088/1748-9326/11/12/124010.

555 Sasson A. 2012. Food security for Africa: an urgent global challenge. Agriculture \& Food

556 Security 1:2. DOI: 10.1186/2048-7010-1-2.

557 Saxena KB, Singh L, Gupta MD. 1990. Variation for natural out-crossing in pigeonpea.

558 Euphytica 46:143-148. DOI: 10.1007/BF00022307. 
559 Steffan-Dewenter I, Kuhn A. 2003. Honeybee foraging in differentially structured landscapes.

560 Proceedings of the Royal Society of London. Series B: Biological Sciences 270:569-575. DOI:

$561 \quad 10.1098 /$ rspb.2002.2292.

562 Steffan-Dewenter I, Münzenberg U, Bürger C, Thies C, Tscharntke T. 2002. SCALE-

563 DEPENDENT EFFECTS OF LANDSCAPE CONTEXT ON THREE POLLINATOR GUILDS.

564 Ecology 83:1421-1432. DOI: 10.1890/0012-9658(2002)083[1421:SDEOLC]2.0.CO;2.

565 Steward PR, Shackelford G, Carvalheiro LG, Benton TG, Garibaldi LA, Sait SM. 2014.

566 Pollination and biological control research: are we neglecting two billion smallholders.

567 Agriculture \& Food Security 3:5. DOI: 10.1186/2048-7010-3-5.

568 Vanlauwe B, Coyne D, Gockowski J, Hauser S, Huising J, Masso C, Nziguheba G, Schut M,

569 Van Asten P. 2014. Sustainable intensification and the African smallholder farmer. Current

570 Opinion in Environmental Sustainability 8:15-22. DOI: 10.1016/j.cosust.2014.06.001. 


\section{Figure 1}

Studied pigeon pea fields in the landscape

Map showing the location of the study fields within its one-kilometre buffer within the study area. The study area marked in red had too much overlap within the one-kilometre radius with the adjacent fields. ESRI Satellite is used as a basemap (ESRI 2020).

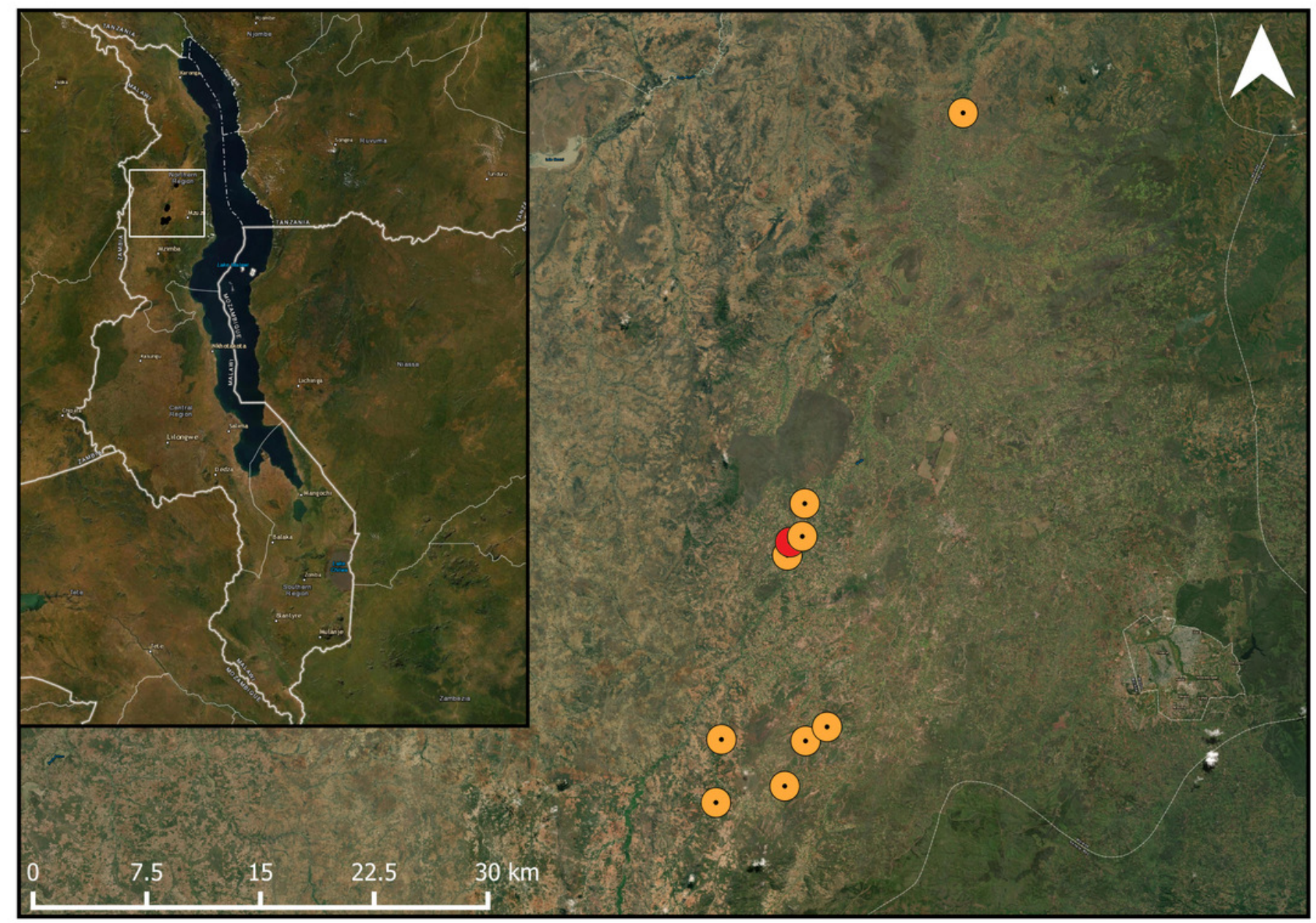


Figure 2

Response of bees and blister beetles to landscape variables

Relationship ( $\pm 95 \% \mathrm{Cl}$ ) between the proportion of semi-natural habitat in the surrounding landscape and a) bee abundance, c) bee richness and e) blister beetle abundance, as well as the relationship between the proportion of agricultural area and b) bee abundance, d) bee richness and f) blister beetle abundance.
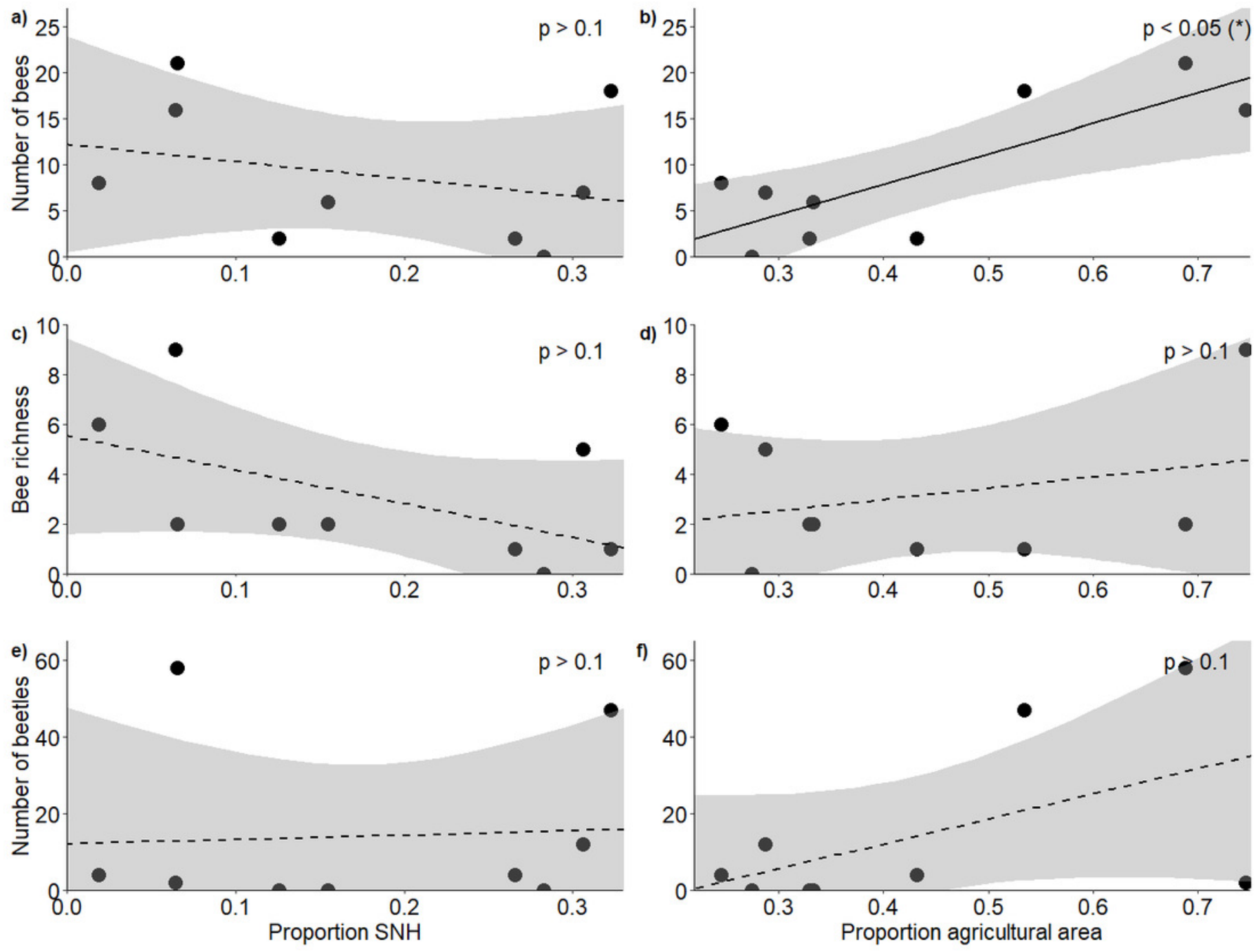


\section{Table 1 (on next page)}

Model summaries of animal responses to landscape composition

Model summary of linear models assessing bee and blister beetle responses to landscape composition (proportion semi-natural habitat and proportion agricultural area) $(n=9)$. 


\begin{tabular}{|c|c|c|c|c|c|c|}
\hline Response & $\begin{array}{l}\text { F-statistic } \\
(2,6)\end{array}$ & Multiple $R^{2}$ & $p$-value & Predictor & $t$-value & $p$-value \\
\hline \multirow{2}{*}{$\begin{array}{l}\text { Bee } \\
\text { abundance }\end{array}$} & \multirow[t]{2}{*}{5.53} & \multirow[t]{2}{*}{0.65} & \multirow[t]{2}{*}{0.043} & SNH & -0.30 & 0.775 \\
\hline & & & & $\begin{array}{l}\text { Agricultural } \\
\text { area }\end{array}$ & 3.11 & $0.021\left(^{*}\right)$ \\
\hline \multirow[t]{2}{*}{ Bee richness } & \multirow[t]{2}{*}{1.38} & \multirow[t]{2}{*}{0.32} & \multirow[t]{2}{*}{0.321} & SNH & -1.43 & 0.203 \\
\hline & & & & $\begin{array}{l}\text { Agricultural } \\
\text { area }\end{array}$ & 0.43 & 0.683 \\
\hline \multirow{2}{*}{$\begin{array}{l}\text { Blister } \\
\text { beetle } \\
\text { abundance }\end{array}$} & \multirow[t]{2}{*}{1.58} & \multirow[t]{2}{*}{0.35} & \multirow[t]{2}{*}{0.281} & SNH & 0.65 & 0.538 \\
\hline & & & & $\begin{array}{l}\text { Agricultural } \\
\text { area }\end{array}$ & 1.77 & 0.127 \\
\hline
\end{tabular}




\section{Table 2 (on next page)}

Summaries of the models assessing the landscape compostion on the proportion of damaged flowers and fruit set difference

Summary of the linear mixed models assessing the effect of landscape composition (proportion semi-natural habitat and proportion agricultural area) on the proportion of damaged flowers and the difference in fruit set between the open and the bagged treatment. 


\begin{tabular}{|c|c|c|c|c|c|}
\hline Response & $\begin{array}{l}\text { Total number of } \\
\text { observations }\end{array}$ & $\begin{array}{l}\text { Number of } \\
\text { groups (n) }\end{array}$ & Predictor & z-value & $p$-value \\
\hline \multirow{2}{*}{$\begin{array}{l}\text { Proportion of } \\
\text { damaged flowers }\end{array}$} & \multirow[t]{2}{*}{135} & \multirow[t]{2}{*}{9} & SNH & 0.05 & 0.960 \\
\hline & & & Agricultural area & -0.78 & 0.439 \\
\hline & & & & $t$-value & $p$-value \\
\hline \multirow{2}{*}{$\begin{array}{l}\text { Difference in fruit } \\
\text { set (open - } \\
\text { bagged) }\end{array}$} & \multirow[t]{2}{*}{89} & \multirow[t]{2}{*}{8} & SNH & -1.83 & 0.125 \\
\hline & & & Agricultural area & -0.19 & 0.853 \\
\hline
\end{tabular}

1 


\section{Table 3(on next page)}

Model assessing the effect of bees and blister beetles on fruit set difference

summaries of the linear mixed model assessing the effect of bee density, bee richness and proportion of damaged flowers on the difference in fruit set between bagged and open flower clusters. 


\begin{tabular}{|l|l|l|l|l|l|}
\hline \multicolumn{4}{|l|}{$\begin{array}{l}\text { Table 3: summaries of the linear mixed model assessing the effect of bee density, bee richness and } \\
\text { proportion of damaged flowers on the difference in fruit set between bagged and open flower clusters. }\end{array}$} \\
\hline Response & $\begin{array}{l}\text { Total number of } \\
\text { observations }\end{array}$ & $\begin{array}{l}\text { Number of } \\
\text { groups }(n)\end{array}$ & Predictor & t-value & $p$-value \\
\hline $\begin{array}{l}\text { Fruit set } \\
\text { differences (open } \\
\text { - bagged) }\end{array}$ & 101 & 9 & Bee density & 0.36 & 0.734 \\
\cline { 3 - 6 } & & Bee richness & 1.45 & 0.196 \\
\cline { 3 - 6 } & & $\begin{array}{l}\text { Proportion of } \\
\text { flowers damaged }\end{array}$ & 1.923 & 0.058 \\
\hline
\end{tabular}

1 